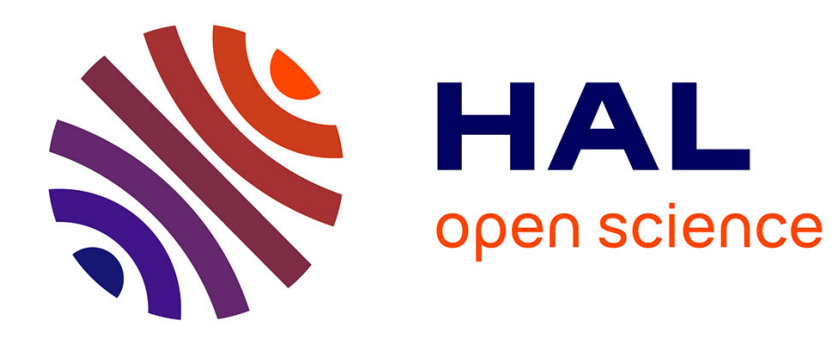

\title{
The oldest known Massoutiera (Rodentia: Ctenodactylinae).
}

Raquel López-Antoñanzas, Fabien Knoll

\section{To cite this version:}

Raquel López-Antoñanzas, Fabien Knoll. The oldest known Massoutiera (Rodentia: Ctenodactylinae).. Mammalia, 2010, 74 (4), pp.461 - 464. 10.1515/mamm.2010.046 . hal-01920964

\section{HAL Id: hal-01920964 \\ https://hal.science/hal-01920964}

Submitted on 12 Dec 2020

HAL is a multi-disciplinary open access archive for the deposit and dissemination of scientific research documents, whether they are published or not. The documents may come from teaching and research institutions in France or abroad, or from public or private research centers.
L'archive ouverte pluridisciplinaire HAL, est destinée au dépôt et à la diffusion de documents scientifiques de niveau recherche, publiés ou non, émanant des établissements d'enseignement et de recherche français ou étrangers, des laboratoires publics ou privés. 


\section{Short Note}

\section{The oldest known Massoutiera (Rodentia: Ctenodactylinae)}

\author{
Raquel López-Antoñanzas* and Fabien Knoll \\ Departamento de Paleobiología, Museo nacional de \\ Ciencias naturales-CSIC, C/José Gutiérrez Abascal 2, \\ 28006 Madrid, Spain, e-mail: ralopan@mncn.csic.es \\ *Corresponding author
}

Keywords: Ctenodactylinae; Holocene; Libya; Ti-n-Thora.

The Ctenodactylidae Gervais 1853 is a family of rodents characterized by a hystricomorphous skull and a sciurognathous lower mandible. It comprises four subfamilies, of which only the Ctenodactylinae are extant. The Ctenodactylinae are known from the Early Miocene to Recent and include 22 species distributed in 14 genera. The four extant genera (Pectinator Blyth 1856, Massoutiera Lataste 1885, Felovia Lataste 1886 and Ctenodactylus Gray 1830) are restricted to areas in north equatorial Africa (Figure 1).

The reference to a possible Pliocene representative of $\mathrm{Pec}$ tinator in Asia (see for instance McKenna and Bell 1997: p. 190) probably comes from Darlington (1957: p. 392). However, this was based on Hinton (1933), who described a fossil lower jaw from India as Pectinator sivalensis. This material was transferred by Black (1972) to the fossil genus Sayimys. Elsewhere, Jaeger (1970: p. 921) cited a "Ctenodactylidae gen. et sp. nov. cf. Felovia" from the Early Pleistocene locality of Irhoud Ocre (Jbel Irhoud, Maroc). On the basis of this material, he later named the species Irhoudia bohlini (Jaeger 1971). Supposedly based on the studies of previous authors (Joleaud 1935, Arambourg 1949, 1952, Arambourg and Coque 1958), Le Houérou (1995: p. 60, 1997: p. 629) mentioned the presence of Ctenodactylus gundi at the Early Pleistocene ( 2.5 Ma, see Gibbard et al. 2010) locality of Ain Brimba (Tunisia). Nevertheless, none of the cited publications indicated the presence of Ctenodactylus at this locality, and thus this record appears dubious (see also Coque 1962). Jaeger (1975: p. 7) merely listed Ctenodactylidae indet. at the same site. For extrinsic reasons (age), it is likely that this material actually belongs to the genus Irhoudia, which is found in the Upper Miocene of Algeria (Jaeger 1977: p. 93, Coiffait-Martin 1991), in the Plio-Pleistocene of Tunisia (Jaeger 1975, Mein and Pickford 1992) and in some Moroccan sites dating from the Mio-Pliocene to the Early Pleistocene (Jaeger 1971, Raynal et al. 1999, Geraads 1995, 1998, 2002). Although the extant ctenodactylines have usually been considered to be known only from the Holocene (Wood 1977, Nowak 1999: p. 1622, they are now noted at the Late Pleistocene site of the Grotte des Pigeons (Ctenodactylus spp.; Taforalt, Morocco) (Bouzouggar et al. 2007).
They are also recorded at the Holocene sites of Redeyef (Table Sud and Table Redeyef, Gafsa, Tunisia) (Vaufrey 1955: p. 394) and Ti-n-Thora (Tadrart Acacus, Libya). The latter specimens are the subject of the present paper. They are described and compared with recent ctenodactylines, and their systematic verification is evaluated below.

The sites of Ti-n-Thora started being excavated during the 1960s and continued during the 1970s and 1980s (Barich 1987a, Di Lernia and Garcea 1997). Three localities are known at Ti-n-Thora: Ti-n-Thora East, Ti-n-Thora North, and Ti-n-Thora Two Caves (Gautier and Van Neer 1982, Barich 1987a,b, Gautier 1987). These localities have been dated by radiocarbon at the institute of geochemistry of the Sapienza Università di Roma by G. Belluomini (Belluomini and Manfra 1987, see also Barich 1984, 1987c). The oldest locality is Ti-n-Thora Two Caves, which has been dated from $9350 \pm 110$ to $8230 \pm 50$ BP $(7400 \pm 110$ to $6280 \pm 50 \mathrm{BC})$, followed in age by Ti-n-Thora East from $9080 \pm 70$ to $7330 \pm 80 \mathrm{BP}$ (7130 \pm 70 to $5380 \pm 80 \mathrm{BC}$ ) and by Ti-n-Thora North from $7070 \pm 60$ to $5260 \pm 130$ BP (5120 \pm 60 to $3310 \pm 130 \mathrm{BC})$.

Ti-n-Thora East was the richest locality from a faunal viewpoint and it has yielded most of the ctenodactyline remains, which were initially identified as Ctenodactylus sp. by Cassoli and Durante (1974). In 1982, Gautier and Van Neer reidentified the Libyan gundi material as Massoutiera mzabi. However, this was not based on a detailed morphological study of the specimens. Based on the distribution of modern ctenodactylines, Gautier and Van Neer (1982) assumed that only Ctenodactylus gundi and Massoutiera mzabi could have been present at Ti-n-Thora (Ctenodactylus vali was frequently used as a subspecies of Ctenodactylus gundi at that time; see for instance Ranck 1968). As the material from Ti-n-Thora is closer in size to Massoutiera mzabi than to Ctenodactylus gundi, they concluded that they were dealing with the former. However, it has not been proven that the difference in size between Ctenodactylus vali (which is smaller than Ctenodactylus gundi; George 1982) and Massoutiera mzabi is significant.

Thus, a detailed study of this material is necessary to confirm or refute its attribution to Massoutiera mzabi. With this end in view, the cranial material available in the collections of the "Research Unit Palaeontology" of the Universiteit Gent (Belgium) under the number P2576 (three hemimandibles from the site of Ti-n-Thora East) was examined and compared with the specimens of the four extant genera of gundis housed in the collections of the Muséum national d'Histoire naturelle (Paris, France) and of the Museum für Naturkunde der Humboldt-Universität (Berlin, Germany).

The three Ti-n-Thora East hemimandibles (Figure 2) correspond to the 7th growth stage of Lataste (1885): adult indi- 


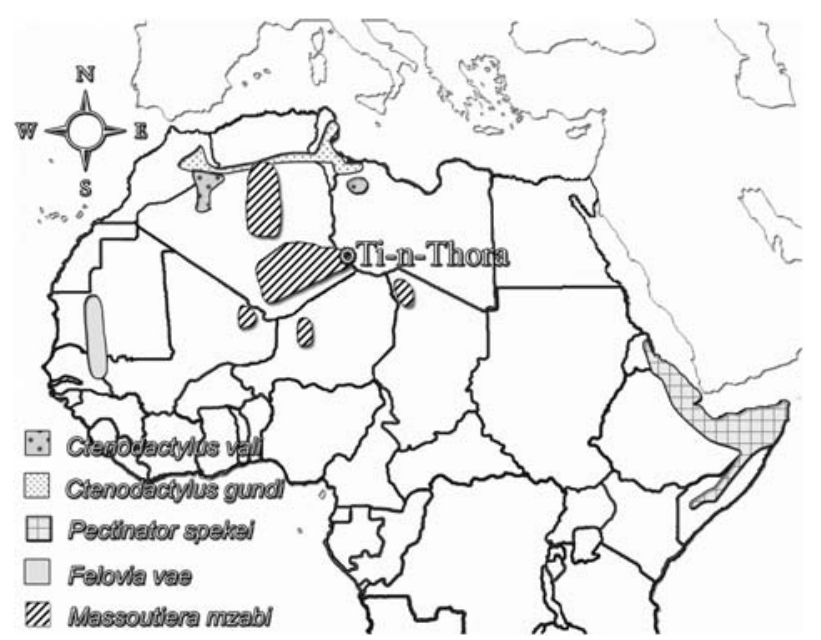

Figure 1 Distribution of the extant Ctenodactylinae (IUCN 2010) and location of the localities of Ti-n-Thora (Libya).

viduals having jaws with the three molars, but lacking any trace of the premolars. The lower molars are rootless and hypsodont. They are bilobed (lacking any trace of metaflexid). The lobes are diagonal, particularly the anterior one, which is very oblique. The protoconid is hypertrophied and the ectolophid is very narrow. The hypoflexid is very deep and it is filled with cement. There is a significant size increase from the first lower molar (m1) to the third (m3). Except for Massoutiera mzabi, the specimens from Ti-n-Thora East differ from all the extant species of the Ctenodactylinae. For instance, they differ from Ctenodactylus gundi and Ctenodactylus vali in having cement on the labial embayment of the lower molars. This characteristic (among others such as the rootless and bilobed lower molars) also precludes its allocation to the genus Pectinator. Within the extant Ctenodactylinae, Massoutiera mzabi and Felovia vae are the taxa that are the most alike, especially regarding the lower molars. However, there are some differences that prevent the allocation of the three mandibles of Ti-n-Thora East to the genus Felovia (e.g., they have no trace of a metaflexid, which is short, but still present, in the lower molars of Felovia). Thus, we confirm the suggestion by Gautier and Van Neer (1982) that the ctenodactyline specimens from Ti-nThora East belong to Massoutiera mzabi.

Massoutiera mzabi has a large, although spotty, geographical range: central and southwestern Algeria, southern Libya, eastern Mali, western Niger, and northwestern Chad (Figure 1). The fact that this species currently lives in the Acacus, as it did around $9000 \mathrm{BP}$, should not be taken as evidence of the same hyperarid climatic conditions as today. First of all, the studies carried out by Gouat et al. (1984) show that Massoutiera mzabi has a physiological and behavioral plasticity that allows it to adapt to a variety of environments. Therefore, this species can live not only in the most inhospitable of places but also in areas with a less extreme climate (e.g., Hoggar), where it co-occurs with a wide variety of animals (Gouat et al. 1984). In addition, the faunal association of Ti-n-Thora East, even though it records a large number of species adapted to arid conditions (Procavia capensis, Paraechinus aethiopicus, Vulpes ruepelli, Gazella dama, Gazella dorcas), also includes widely distributed taxa (Hystrix cristata, Lepus capensis, Canis aureus, Felis silvestris, Galerella sanguinea, Herpestes ichneumon), as well as species characteristic of savannah (Panthera leo, Papio cynocephalus sensu lato). All in all, the fauna of Ti-n-Thora resembles the fauna that currently (or until recently) dwells in areas of the transition zone between the Sahara desert and the tropical regions of Africa (Sahel), as well as the fauna present in the ecoregion of the Tibesti Mountains. Today, the semidesert/desert boundary in North Africa is located at approximately $30^{\circ} \mathrm{N}$ latitude (Schulz et al. 2009: p. 70, figure $1)$. The Sahel, which today is located around $18^{\circ} \mathrm{N}$ latitude, extended up to $23^{\circ} \mathrm{N}$ latitude during the African Humid Period ( 11500-5500 BP) (Jolly et al. 1998, Claussen et al. 2002, Renssen et al. 2006, Schütt and Krause 2009). Similarly, in northern Africa, the semidesert/desert boundary is

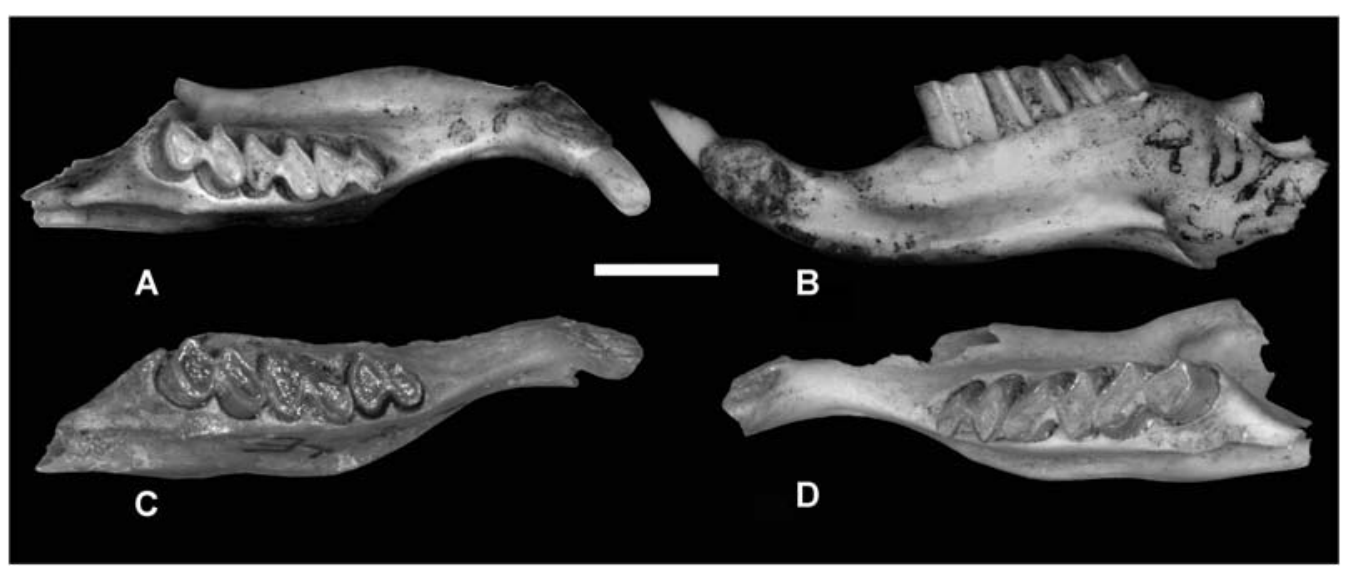

Figure 2 Massoutiera mzabi from Ti-n-Thora (specimens P2576). (A) Right hemimandible with m1-m3 in occlusal view; (B) same specimen in medial view; (C) right hemimandible with $\mathrm{m} 1-\mathrm{m} 3$ in occlusal view; (D) left hemimandible with $\mathrm{m} 1-\mathrm{m} 3$ in occlusal view. Scale bar $=4 \mathrm{~mm}$. 
expected to have progressed to the south, namely towards the Tadrart Acacus. Thus, it is likely that Ti-n-Thora 9000 $\mathrm{BP}$ was not a desert as is today but rather a semiarid zone.

\section{Acknowledgements}

We sincerely thank J. Cuisin (Muséum national d'Histoire naturelle, Paris) and F. Mayer and S. Jancke (Museum für Naturkunde der Humboldt-Universität, Berlin) for having made available the modern ctenodactylid material under their care. Our stay in Berlin was funded by the Alexander von Humboldt Foundation through sponsorships of renewed research stays in Germany. A. Gautier (Universiteit Gent, Ghent) kindly provided the specimens for this study and helped improve this manuscript through critical reading. J. Baskin (Texas A\&M University, Kingsville), D. Geerads (CNRS UPR 2147, Paris), P. Gouat (Université Paris 13, Villetaneuse) and an anonymous reviewer helped to improve various aspects of this paper. The authors are currently supported by the Ramón y Cajal Program and the research projects CGL2008-05813-CO2-01 directed by J. Morales (Museo nacional de Ciencias naturales-CSIC, Madrid) and CGL2009-12143 directed by F.K.

\section{References}

Arambourg, C. 1949. Les gisements de Vertébrés Villafranchiens de l'Afrique du Nord. Bull. Soc. Géol. Fr. 14: 195-203.

Arambourg, C. 1952. La paléontologie des vertébrés en Afrique du Nord française. In: XIX ${ }^{\text {ème }}$ Congrès Géologique International, Alger.

Arambourg, C. and R. Coque. 1958. Le gisement villafranchien de l'Aïn Brimba (Sud-Tunisien) et sa faune. Bull. Soc. Géol. Fr. 8: 607-614.

Barich, B.E. 1984. Fieldwork in the Tadrart Acacus and the "Neolithic" of the Sahara. Curr. Anthropol. 25: 683-686.

Barich, B.E. 1987a. Methodology and history of the research in the Tadrart Acacus area. In: (B.E. Barich, ed.) Archaeology and environment in the Libyan Sahara. The excavations in the Tadrart Acacus, 1978-1983. British Archaeological Reports International Series No. 368. pp. 3-12.

Barich, B.E. 1987b. The two Caves shelter: an Early Holocene site in the North-Eastern Acacus. In: (B.E. Barich, ed.) Archaeology and environment in the Libyan Sahara. The excavations in the Tadrart Acacus, 1978-1983. British Archaeological Reports International Series No. 368. pp. 13-62.

Barich, B.E. 1987c. The Tadrart Acacus contribution to the study of cultural change in the Sahara. In: (B.E. Barich, ed.) Archaeology and environment in the Libyan Sahara. The excavations in the Tadrart Acacus, 1978-1983. British Archaeological Reports International Series No. 368. pp. 331-347.

Belluomini, G. and L. Manfra. 1987. Radiocarbon dates from the Tadrart Acacus massif. In: (B.E. Barich, ed.) Archaeology and environment in the Libyan Sahara. The excavations in the Tadrart Acacus, 1978-1983. British Archaeological Reports International Series No. 368. pp. 327-330.

Black, C.C. 1972. Review of fossil rodents from the Neogene Siwalik Beds of India and Pakistan. Palaeontology 15: 238-266.

Blyth, E. 1856. Report on a zoological collection from the Somali country. J. Asiat. Soc. Bengal 24: 291-306.

Bouzouggar, A., N. Barton, M. Vanhaeren, F. d'Errico, S. Collcutt,
T. Higham, E. Hodge, S. Parfitt, E. Rhodes, J.L. Schwenninger, C. Stringer, E. Turner, S. Ward, A. Moutmir and A. Stambouli. 2007. 82,000-year-old shell beads from North Africa and implications for the origins of modern human behavior. Proc. Natl. Acad. Sci. USA 104: 9964-9969.

Cassoli, P.F. and S. Durante. 1974. La fauna del Ti-n-Torha (Acacus, Libia). Origini 8: 159-161.

Claussen, M., V. Brovkin and A. Ganopolski. 2002. Africa: greening of the Sahara. In: (W. Steffen, J. Jäger, D.J. Carson and C. Bradshaw, eds) Challenges of a changing Earth. Springer, Berlin. pp. $125-128$.

Coiffait-Martin, B. 1991. Contribution des rongeurs du Néogène d'Algérie à la biochronologie mammalienne d'Afrique nordoccidentale. Doctoral thesis. Univ. Nancy 1. pp. 389.

Coque, R. 1962. La Tunisie présaharienne: étude géomorphologique. Doctoral thesis. Université de. Paris. pp. 467.

Darlington, P.J. 1957. Zoogeography: the geographical distribution of animals. John Wiley and Sons, New York. pp. 675.

Di Lernia, S. and E. Garcea. 1997. Some remarks on Saharan terminology. Pre-pastoral archaeology from the Lybian Sahara and the Middle Nile Valley. Libya Antiqua 3: 11-24.

Gautier, A. 1987. The archaeozoological sequence of the Acacus. In: (B.E. Barich, ed.) Archaeology and environment in the Libyan Sahara. The excavations in the Tadrart Acacus, 1978-1983. British Archaeological Reports International Series No. 368. pp. 283-312.

Gautier, A. and W. Van Neer. 1982. Prehistoric fauna from Ti-nTorha (Tadrart Acacus, Libya). Origini 11: 87-127.

George, W. 1982. Ctenodactylus (Ctenodactylidae, Rodentia): one species or two? Mammalia 46: 375-380.

Geraads, D. 1995. Rongeurs et insectivores (Mammalia) du Pliocène final de Ahl al Oug (Casablanca, Maroc). Geobios 28: 99-115.

Geraads, D. 1998. Rongeurs du Mio-Pliocène de Lissasfa (Casablanca, Maroc). Geobios 31: 229-245.

Geraads, D. 2002. Plio-Pleistocene mammalian biostratigraphy of Atlantic Morocco. Quaternaire 13: 43-53.

Gervais, M.P. 1853. Description ostéologique de l'Anomalurus et remarques sur la classification naturelle des rongeurs. Ann. Sci. Nat. Zool. 20: 238-246.

Gibbard, P.L., M.J. Head, M.J.C. Walker and the Subcommission on Quaternary Stratigraphy. 2010. Formal ratification of the Quaternary System/Period and the Pleistocene Series/Epoch with a base at 2.58 Ma. J. Quaternary Sci. 25: 96-102.

Gouat, P., J. Gouat and J. Coulon. 1984. Répartition et habitat de Massoutiera mzabi (Rongeur Cténodactylidé) en Algérie. Mammalia 48: 351-362.

Gray, J.E. 1830. Spicilegia zoologica: original figures and short systematic descriptions of new and unfigured animals. Partie 2. Treüttel, Würtz and Co, London.

Hinton, M.A.C. 1933. Diagnoses of new genera and species of rodents from Indian Tertiary deposits. Ann. Mag. Nat. Hist. 12: $620-622$.

IUCN. 2010. IUCN red list of threatened species. Version 2010.1. Available at $<$ www.iucnredlist.org $>$.

Jaeger, J.J. 1970. Découverte au Jebel lrhoud des premières faunes de rongeurs du Pléistocène inférieur et moyen du Maroc. C.R. Acad. Sci. Paris, Ser. D, 270: 920-923.

Jaeger, J.J. 1971. Un Cténodactylidé (Mammalia, Rodentia) nouveau, Irhoudia bohlini n.g. n. sp. du Pléistocène inférieur du Maroc, rapports avec les formes actuelles et fossiles. Notes Serv. Géol. Maroc 31: 113-140.

Jaeger, J.J. 1975. Les Muridae (Mammalia, Rodentia) du Pliocène et du Pléistocène du Maghreb. Origine; evolution; Données bio- 
géographiques et paléoclimatiques. Doctoral thesis. Univ. Sciences et Techniques du Languedoc-Montpellier II. pp. 124.

Jaeger, J.J. 1977. Les rongeurs du Miocène moyen et supérieur du Maghreb. Palaeovertebrata 8: 1-166.

Joleaud, L. 1935. Gisements de Vertébrés quaternaires du Sahara. Bull. Soc. Hist. Nat. Afr. Nord 23 bis: 23-39.

Jolly, D., S.P. Harrison, B. Damnatl and R. Bonnefille. 1998. Simulated climate and biomes of Africa during the Late Quaternary: comparison with pollen and lake status data. Quat. Sci. Rev. 17: 629-657.

Lataste, F. 1885. Sur le système dentaire du genre Ctenodactylus Gray. Le Naturaliste 21-22.

Lataste, F. 1886. Novi subgeneris et novæ speciei rodentium, e genere Massoutiera diagnoses. Le Naturaliste 36: 287.

Le Houérou, H.N. 1995. Bioclimatologie et biogéographie des steppes arides du Nord de l'Afrique: diversité biologique, développement durable et désertisation. CIHEAM, Montpellier. pp. 396.

Le Houérou, H.N. 1997. Climate, flora and fauna changes in the Sahara over the past 500 million years. J. Arid Environ. 37: 619-647.

McKenna, M.C. and S.K. Bell. 1997. Classification of mammals above the species level. Columbia University Press, New York. pp. 631.

Mein, P. and M. Pickford. 1992. Gisements karstiques pléistocènes au Djebel Ressas, Tunisie. C.R. Acad. Sci. Paris, Ser. II 315: 247-253.
Nowak, R.M. 1999. Walker's mammals of the world. The John Hopkins University Press, Baltimore. pp. 2015.

Ranck, L.G. 1968. The rodents of Libya, taxonomy, ecology and zoogeographical relationships. Bull. U.S. Nat. Mus. 275: 1-264.

Raynal, J.P., D. Lefèvre, D. Geraads and M. El Graoui. 1999. Contribution du site paléontologique de Lissasfa (Casablanca, Maroc) à une nouvelle interprétation du Mio-Pliocène de la Méseta. C.R. Acad. Sci. Paris Ser. IIa 329: 617-622.

Renssen, H., V. Brovkin, T. Fichefet and H. Goosse. 2006. Simulation of the Holocene climate evolution in Northern Africa: the termination of the African Humid Period. Quat. Int. 150: 95-102.

Schütt, B. and J. Krause. 2009. Comparison of proxy-based palaeoenvironmental reconstructions and hindcast modelled annual precipitation - a review of Holocene palaeoenvironmental research in the Central Sahara. In: (R. Baumhauer and J. Runge, eds) Holocene palaeoenvironmental history of the Central Sahara. CRC press, Boca Raton, FL. pp. 23-37.

Schulz, E., A. Abichou, A. Adamou, A. Ballouche and I. Ousseini. 2009. The desert in the Sahara. Transitions and boundaries. In: (R. Baumhauer and J. Runge, eds) Holocene palaeoenvironmental history of the Central Sahara. CRC press, Boca Raton, FL. pp. 63-89.

Vaufrey, R. 1955. Préhistoire de l'Afrique. Vol. 1. Masson, Paris. pp. 458.

Wood, A.E. 1977. The evolution of the rodent family Ctenodactylidae. J. Palaeontol. Soc. India 20: 120-137. 